\title{
OBSERVATIONS ON THE FORAGE POTENTIAL OF VELVET BEAN
}

\author{
V. RAVINDRAN \\ Department of Animal Science, University of Peradeniya, Peradeniya, Sri Lanka.
}

(Date of receipt : 24 November 1987)

(Date of acceptance : 12 February 1988)

\begin{abstract}
A field trial was conducted with velvet bean (Mucuna spp.) planted during the Maha season of $1983 / 84$. Whole crop samples of the above ground dry matter were taken at four different stages of growth $(60,90,120$ and 150 days) to assess the interaction of dry matter yield and forage quality during maturity. Dry matter yield increased with maturity, but quality parameters steadily declined. The results suggest that the velvet bean forage should be harvested around 90 days. Harvested at this maturity, a dry matter yield of 3.1 tonnes per hectare, with a crude protein content of $20.6 \%$ and $55.4 \%$ in vitro digestibility; could be obtained.
\end{abstract}

\section{Introduction}

The usefulness of legumes as components in forage mixtures is well recognised. The beneficial effects attributed to the legume derive partly from its ability to fix atmopheric nitrogen and partly from the high protein contents of its dry matter. ${ }^{14,20}$ In Sri Lanka, at least on account of the latter reason, establishment of legumes is justified.

Velvet bean (Mucuna spp; Syn Stizolobium spp), ${ }^{20}$ which was originally introduced as a cover crop in coconut plantations, has the potential as a forage crop. The major characteristics of this forage legume has been recently reviewed ${ }^{11}$ and, in fact, its use is recommended for the hill country region. ${ }^{12}$ The study reported herein is a preliminary attempt to assess the productivity and nutritive value of velvet bean forage at four different growth stages. Such assessment has not been reported previously for velvet bean grown in Sri Lanka.

\section{Materials and Methods}

\subsection{Description}

Several selections of velvet bean are known to exist in Sri Lanka, ${ }^{16}$ but the exact classification is difficult as the taxonomy of the species is confusing. ${ }^{6}$ They are all annual-perennial legumes with vigorously growing vines which may extend up to $6 \mathrm{~m}$ in length. The leaves are trifoliate with large, ovate leaflets. The white to dark purple flowers appear in long pendant clusters. Pods, 10 to 14 in a cluster, are borne singly and have a greyish-white pubescence of short, silky hairs. Three seedcoat colour types, namely black, white and mottled, are common. 15,20,23 
Originating in India, it is now naturalized in all tropical countries. Their distribution has been extended into the temperate countries by breeding. ${ }^{23}$ The legume is tolerant to drought due to its deep roots. ${ }^{6,15}$

The velvet bean variety used in the present evaluation was black-seeded. The seeds were obtained from the Coconut Research Institute, Lunuwila.

\subsection{Growing conditions}

Velvet beans were planted (three seeds per hill) at a spacing of $60 \times 60 \mathrm{~cm}$ during the $1983 / 84$ Maha season in an experimental plot $(6.0 \times 12.0 \mathrm{~m})$ at the Department of Animal Science, University of Peradeniya. The soil at the site was reddish brown latasolic soil with a $\mathrm{pH}$ of 6.1 . A well distributed rainfall was received during the experimental period.

The plot received a basal application of one tonne of poultry litter/ha (equivalent to approximately $52 \mathrm{~kg} \mathrm{~N}, 36 \mathrm{~kg} \mathrm{P}_{2} \mathrm{O}_{5}$ and $35 \mathrm{~kg} \mathrm{~K}_{2} \mathrm{O}$ per hectare) at planting. The stand was thinned to two plants per hill after one month and bamboo trellises were provided for support. The supports were given mainly to prevent matting of plants from adjacent hills and to facilitate the yield estimations.

\subsection{Sampling procedures}

The flowering in velvet beans commences around 90 days and continues for another $50-70$ days. The sampling of the forage was done at 60 days (pre-bloom), 90 days (start of bloom), 120 days (mid-bloom) and 150 days (post-bloom). At each age of harvesting, twenty plants (from ten hills) were randomly selected and cut $10 \mathrm{~cm}$ above ground. Leaves and stems (and pods at 120 and 150 days of age) from each plant were hand-separated, and weights were recorded. Sub-samples (ca $500 \mathrm{~g}$ ) of the different anatomical parts were removed to the laboratory for dry matter determination. Further sub-samples (ca $2 \mathrm{~kg}$ ) were taken and dried at $60^{\circ} \mathrm{C}$ in an unitherm oven for $36-48$ hours. The dried samples were then ground and stored in air tight plastic jars for subsequent laboratory evaluation.

Velvet bean pods and seeds are also reported to have been used for livestock feeding. ${ }^{6,15}$ For this reason, samples of green pods (immature and mature), seeds and pod husks were also collected for analysis.

\subsection{Analytical procedures}

The dry matter, crude protein, ether extract and ash contents were determined according to standard procedures. ${ }^{2}$ The detergent fibre composition was determined using the method of Goering and Van Soest. ${ }^{9}$ In vitro organic matter digestibility (IVOMD) was determined according to the method of Tilley and Terry ${ }^{22}$ as modified by Barnes. ${ }^{3}$ Rumen liquor was 
collected from two fistulated cattle which have been previously fed a mixture of straw and legumes. Five standard samples of known in vivo digestibility were used in each in vitro run to correct for run-to-run variation. The standard samples consisted of legume and straw samples.

\section{Results and Discussion}

The forage dry matter yields of velvet bean increased with maturity (Table 1). The observed yields are in the same range as those reported by King et.al. ${ }^{13}$ in Australia and by Takahashi and Ripperton ${ }^{21}$ in Hawaii.

Table 1. Some productive parameters of velvet bean forage.

\begin{tabular}{|c|c|c|c|c|c|c|}
\hline \multirow[t]{2}{*}{$\begin{array}{l}\text { Age } \\
\text { (days) }\end{array}$} & \multirow{2}{*}{$\begin{array}{l}\text { Dry } \\
\text { matter } \\
(\%)\end{array}$} & \multicolumn{2}{|c|}{ Total dry matter production ${ }^{a}$} & \multicolumn{3}{|c|}{$\begin{array}{l}\text { Major anatomical fractions } \\
(\%)\end{array}$} \\
\hline & & g/plant/cut ${ }^{b}$ & $\mathrm{~kg} / \mathrm{ha} / \mathrm{cut}^{\mathrm{c}}$ & Leaf & Stem & $\begin{array}{l}\text { Reproductive } \\
\text { parts }\end{array}$ \\
\hline 60 & 18.2 & 61 & 1660 & 54.6 & 45.4 & - \\
\hline 90 & 21.1 & 114 & 3103 & 47.9 & 52.1 & - \\
\hline 120 & 23.7 & 161 & 4383 & 41.1 & 55.1 & 3.8 \\
\hline 150 & 20.4 & 194 & 5282 & 30.3 & 60.4 & 9.3 \\
\hline
\end{tabular}

. I Includes reproductive parts in plants harvested at 120 and 150 days of age.

b Mean of twenty plants.

c Extrapolated yield based on a plant density of $27,225 / \mathrm{ha}$.

The relative dry weight distribution of different anatomical parts (Table 1) show that at 60 days the leaves constituted $55 \%$ whereas only $45 \%$ was stems. This changed during growth to $30 \%$ leaves and $61 \%$ stems by 150 days. The reproductive parts, mainly pods, constituted the balance $9 \%$. The general tendency of a decreasing leaf:stem ratio during growth is in agreement with previous studies reported for other tropical and temperate legumes. ${ }^{1,20}$ 
Table 2. Chemical composition and IVOMD of velvet bean forage at four different stages of growth (percentage DM basis).

\begin{tabular}{lrrrr}
\hline \multirow{2}{*}{ Parameter } & \multicolumn{3}{c}{ Plant age (days) } \\
\cline { 2 - 5 } & \multicolumn{1}{c}{60} & \multicolumn{1}{c}{90} & 120 & \multicolumn{1}{c}{150} \\
\hline Crude protein & 24.80 & 20.61 & 14.75 & 12.84 \\
Ether extract & 2.78 & 2.72 & 2.51 & 2.39 \\
Ash & 5.52 & 5.79 & 4.55 & 6.43 \\
Acid detergent fibre & 33.15 & 40.12 & 45.83 & 47.91 \\
Cell wall & 40.26 & 51.35 & 56.78 & 59.15 \\
Cell contents & 59.74 & 48.65 & 43.22 & 40.85 \\
Hemicellulose & 7.11 & 11.23 & 10.95 & 11.24 \\
Cellulose & 27.85 & 31.12 & 36.24 & 37.50 \\
Permanganate lignin & 3.87 & 5.92 & 7.75 & 8.96 \\
Silica & 0.65 & 1.07 & 1.63 & 1.85 \\
IVOMD & 66.41 & 55.35 & 50.60 & 42.23 \\
& & & & \\
\hline
\end{tabular}

As shown in Table 2, the velvet bean forage contained $20.6-24.8 \%$ crude protein during the pre-bloom stage. The crude protein content declined rapidly with flowering, due to a redistribution of nitrogen to the seeds. ${ }^{5}$ Despite this decline, the crude protein content of the legume herbage (even at $\mathbf{1 5 0}$ days) remained at a higher level than of common grasses available in Sri Lanka. ${ }^{10}$

Cell walls are a major part of the plant. The amount and composition of the cell walls is probably the most important factor influencing the nutritive value of forages. ${ }^{4}$ But studies of the composition of the cell walls in tropical forages are scanty. As such, comparison of the present data with other work is not possible. The data (Table 2) shows that all cell wall components steadily increased with maturity.

The in vitro digestibility of the velvet bean forage decreased from $66.4 \%$ to $42.2 \%$ as the plant matured. This is to be expected, since the general trend of decline in the digestibility of forage crops with plant maturity is well documented. ${ }^{8,19}$ This decrease can be attributed to a combination of factors inter alia decreasing leaf to stem ratio, decreasing amount of crude protein, increasing amount of cell walls and increasing lignification. Although not reported separately in the present data, the fact that the chemical composition of leaves and stems during crop maturity followed distinctly different patterns needs a special mention. The contents 
of crude protein, cell walls and lignin and in vitro digestibility of the leaf fraction changed only a small extent during maturity, while in the stems all these parameters decreased rapidly.

Table 3. Chemical composition and IVOMD of some reproductive parts of velvet bean.

\begin{tabular}{lcccc}
\hline Parameter & $\begin{array}{l}\text { Immature } \\
\text { green pod }\end{array}$ & $\begin{array}{l}\text { Mature } \\
\text { green pod }\end{array}$ & $\begin{array}{l}\text { Mature } \\
\text { seed }\end{array}$ & $\begin{array}{l}\text { Pod } \\
\text { husk }\end{array}$ \\
\hline DM (\%) & 30.66 & 41.56 & 88.50 & 91.60 \\
\% DM basis & & 19.29 & 26.45 & 3.13 \\
Crude protein & 14.68 & 4.80 & 4.32 & 3.88 \\
F.ther extract & 4.21 & 3.85 & 3.46 & $4: 87$ \\
Ash & 3.94 & 31.89 & 10.91 & 40.70 \\
ADF & 27.33 & 59.11 & 21.90 & 64.81 \\
Cell wall & 53.96 & 40.89 & 78.10 & 35.19 \\
Cell contents & 46.04 & 27.22 & 10.99 & 24.11 \\
Hemicellulose & 22.63 & 23.81 & 9.34 & 29.80 \\
Cellulose & 20.10 & & & 8.60 \\
Permanganate & 6.39 & 7.03 & 0.80 & 1.10 \\
Silica & 0.60 & 0.65 & 0.40 & 40.50 \\
IVOMD \% & 67.50 & 58.10 & 70.70 & \\
\hline
\end{tabular}

Surprisingly the mature green pods had a higher crude protein content than tender green pods (Table 3); but the IVOMD of mature pods was lower. The crude protein and IVOMD values of mature velvet bean seeds were $26.4 \%$ and $70.7 \%$, respectively. These values compare closely to those reported for the common food legumes grown in the Asian continent. ${ }^{7}$ Recent reports suggest that the velvet bean seeds have potential as a protein source both in human and animal nutrition. ${ }^{17,18}$ The data show pod husks to be a poor quality roughage. The crude protein content and IVOMD value of pod husks are similar to those generally quoted for paddy straw. 10

On the strength of these preliminary results, the forage potential of velvet bean appears good. The data indicate that the velvet bean forage should be harvested around 90 days. Harvested at this age, velvet bean would provide a yield of $3100 \mathrm{~kg} / \mathrm{ha}$ of moderate quality $(20.6 \%$ crude protein and $55.3 \%$ IVOMD) forage dry matter. The productivity of velvet bean forage is sufficiently encouraging to warrant further field trials. The persistency of the legume under repeated harvesting and its compatibility with companion grasses are aspects that need be evaluated in future studies. 


\section{Acknowledgement}

Prof. A. S. B. Rajaguru is gratefully acknowledged for initiating this study on velvet bean. Mr. A. R. K. Rajapakse is thanked for his technical assistance. The study was supported by an International Foundation of Science (Sweden) grant.

\section{References}

1. AMAN, P. \& NORDKVIST, E. (1983) J. Sci, Food Agric. 34: 1185-1189.

2. AOAC (1970) Official Metbods of Analysis, 11th edition. Association of Official Analytical Chemists, Washington, D.C. .

3.. BARNES, R.F. (1969) Proc. 10tb Intl. (jrassl. Cong. $10: 434-440$.

4. BEN-GHEDALIA, D. \& MIRON, J (1984). J.Nutr. 114: 880-887.

5. CROWDER, L.V. \& CHHEDA, H.R. (1982) Tropical Grassland Husbandry. London and New York: Longman.

6. DUKE, J.A. (1981) Handbook of Legumes of World Economic Importance. New York and L.ondon: Plcnum Press.

7. FAO (1972) Food Composition Table for Use in liast Asia. Rome: Food and Agriculture Organization.

8. GAill.ARD, B.D.E. (1962) J. Agric. Sci. (Camb.). 59: 369-373.

9. COOERING, H.K. \& VAN SOEST, P.J. (1970) Forage Fibre Analysis (Apparatus, reagents, procedures and some applications). USDA Handbook No. 279, Washington, DC: U.S. Printing Office.

10. IBRAHIM, M.N.M., KETELAAR, R.S., TAMMINGA, S., ZEMMELINK, G. \& VAN DER MFER, J.M. (1987) IVVO Report No. 181. Lelystad, The Netherlands: Institute for Livestock Feeding and Nutrition Research (IVVO).

11. JAYAWARDENE, A.B.P. (1980) Anim. Prod. Hlth Bull. 13: 33-34.

12. JAYAWARDENE, A.B.P. (1985) Trop. Agric. Rese'arch Series (Japan). 18 : 71-86.

13: KING, N.J., MUNGOMERY, R.W. \& HUGHES, C.G. (1965) Manual of Cane Growing. Sydney: Angus and Robertson.

14. NORRIS, D.O. (1972) Trop. Grassld. $6: 159-169$.

15. PAUL, W.R.C. (1951) Trop. Agric. (Colombo). $107:$ 15-20.

16. PIERIS, N., JANSZ, E.R. \& DHARMADASA, H.M. (1980) J. Natn. Sci. Coun. Sri lanka. $8: 35-40$. 
17. RAJAGURU, A.S.B. (1987) Proc. Workshop on Improved Production and Utilization of Fuod Legumes in Sri Lanka. Gannoruwa, Sri Lanka. June 22-26, 1987 (Mimeo.).

18. RAVINDRAN, V., RAVINDRAN, G., RAJAGURU, A.S.B. \& RAJAPAKSE, A.R.K. (1987) Ibid. Gannoruwa, Sri Lanka, June 22-26, 1987 (Mimeo).

19. REID, R.L., POST, A.J., OLSEN, F.J. \& MUGERWA, J.S. (1973) Trop. Agric. (Trin.) 50 :1-15.

20. SKERMAN, P.J. (1977) Tropical Forage Legumes. Rome : Food and Agriculture Organization of the United Nations.

21. TAKAHASHI, M. \& RIPPERTON, J.C. (1949) Hawaii Agric. Exp. Sta. Bull. No. 100.

22. TILLEY, T.M.A. \& TERRY, R.A. (1963) J. Brit. Grassld. Soc. 18 : 104-111.

23. WHYTE, R.O., NILSSON-LEISSNER, G. \& TRUMBLE, H.C. (1953) Legumes in Agriculture. FAO Agric. Studies No. 22. Rome : FAO.

21. TAKAHAS.HI, M. \& RIPPERTON, J.C. (1949) Hawaii Agric. Exp. Sta. Bull. No. 100. 